\title{
【論文】
}

\section{静置通気型反応器を用いた生物系廃较物の好気微生物反応による 乾燥のシミュレーション}

\author{
金子栄 廣 * . 伊 藤 浩二郎 *
}

【要 旨】生物系廃棄物の多くは水分を多く含むが乾燥させれば燃料として利用できる程度の発熱量を もち, 効率よく乾燥させれば燃料化できる可能性がある。一方, 生物系廃棄物の資源化方法の一つとし て好気微生物反応を利用したコンポスト化がある。この反応では反応熱による材料の昇温と好気条件を 維持するために行われる通気によって乾燥が進む。これをうまく活用すれば効率よい乾燥を行えると考 えられる。しかし，この反応はさまざまな環境・操作因子が関連する複雑な反応なため, 最適な運転管 理条件を見いだすのが容易ではない。実験だけでなくシミュレーションを活用できれば最適運転条件の 検討に役立つ。本研究では, 静置通気型反応器を用いた場合の生物系廃棄物乾燥のシミュレーションプ ログラムを作成した。また, 乾燥実験結果を行い, 実験結果とシミュレーション結果を比較してシミュ レーションの妥当性について考察した。

キーワード: 生物系廃棄物, 乾燥, 好気微生物反応, 静置通気型反応器, シミュレーション

\section{1.はじめに}

生ごみや下水污泥等の生物系廃棄物の多くは水分を多 く含むが, 乾燥させればごみ固形燃料 $(\mathrm{RDF})$ と同程 度の発熱量を示すものがあり ${ }^{11}$, 燃料として利用できる 可能性が高い。現に, 下水污泥についてはバイオマスエ ネルギー有効利用の観点からバイオガス化とならんで固 形然料化が進められている2)。また, 生ごみや生ごみを 含む可燃ごみをコンポスト化と類似の好気微生物処理を 行って乾燥させ, 乾燥物を固形燃料として利用する取り 組みを進めている自治体もある3.4)

ところで, 通常行われているコンポスト化は, 対象廃 棄物を安定化させて緑農地還元可能な製品にすることを 主目的としている。しかし, 水分に着目してその反応過 程をみてみると, 反応に伴う発熱により材料温度が上昇 すると同時に，好気条件を保つために行われる通気や切

原稿受付 2017.8.30 原稿受理 2018.1.15

*山梨大学大学院 総合研究部工学域土木環境工学系 連絡先： $7400-8511$ 山梨県甲府市武田 4-3-11

山梨大学大学院 総合研究部工学域土木環境工学系金子 栄廣 E-mail : kaneko@yamanashi.ac.jp
り返しによって材料が外気に晒されるので乾燥が進む。 この現象を活用すれば, 生物系廃棄物を効率よく乾燥さ せ, 固形燃料として利用する途を開くことができるので はないかと期待される。

大熊らは湿潤バイオマスをエネルギー自立型炭化の原 料にするための方法として発醰乾燥技術の導入を提案し て扔り ${ }^{5)}$ ，前らはこのプロセスがエクセルギー効率の観 点から有用であると述べている ${ }^{6)}$ 。著者らは生物分解成 分を含む材料と含まない材料を用いた生物分解乾燥実験 を行い, 前者の材料のほうが後者に比べて温度が高くな るために早く乾燥が進むこと, ならびに生物系廃棄物の 分解に伴う反応熱で水分蒸発や材料等の昇温に必要 な熱量を賄えることを示した7)。ほかにも都市ごみや 下水污泥を対象に好気微生物反応を利用した乾燥（biodrying) を行って然料化するための研究 8.9 が行われてい る。また, bio-dryingはヨーロッパ等で普及している機 械的生物処理（MBT）の要素技術の一つとして実用化 している ${ }^{10)}$ 。

以上のことから, 好気微生物反応を利用した生物系廃 棄物の乾燥処理はエネルギー回収方法の一つとして有望 と考えられる。しかし，この反応はコンポスト化と同様， さまざまな環境因子や操作因子が相互に関係する複雑な 
反応であり，最適な運転管理条件を見いだすのは容易で はない。たとえば Zhang らは実験室規模の筒型反応器 を用いて都市ごみの bio-drying 効率に通気速度や植種 が与える影響を調べている ${ }^{11)}$ が，ほかにも材料の性状, 通気の温度や湿度, 外気の温度, 反応器の断熱性等, さ まざまな因子が反応や乾燥の進み方に影響を与えるので, 実験だけで最適運転管理条件を見いだすのは容易でない。 このような問題を解決する手段の一つとして, 著者ら はコンポスト化反応における各因子と反応速度の関係を 数理モデルとして捉えてシミュレーションする方法を提 案してきた ${ }^{12,13)}$ 。また現在では, これを乾燥処理に応用 することを目的として検討を進めている ${ }^{14)}$ 。本研究では, 静置通気型反応器を用いた場合の生物系廃棄物乾燥過程 を再現するためのシミュレーションプログラムの作成を 目的とした。また，模擬廃棄物を用いた乾燥実験を行い， 実験結果をシミュレーションの計算結果と比較すること で,シミュレーションの妥当性について考察した。

なお, 本研究で対象とする静置通気型反応器は材料の 切り返しを行わず通気のみを行う反応器で, 攪挥動力を 必要としないという特長がある。また, 下部から通気を 行った場合, 下部から上に向かって乾燥が進行するので, 反応器全体では乾燥が終了していなくても下部では材料 は十分乾燥した状態になる ${ }^{15)}$ 。したがって fill-anddraw 方式の運転を行うことで連続的な乾燥物の取り出 しが期待できる。

\section{2. 乾燥実験の方法}

本研究で作成するシミュレーションプログラムの妥当 性を検証するには, その計算結果と実験結果とを比較す る必要がある。また, シミュレーションに必要ないくつ かのパラメータは実験結果に基づき較正する必要がある。 そこで, 実験室規模の静置通気型反応器を用いて乾燥実 験を行った。

実験に用いた装置の概要を図 1 に示す。アクリル製の 円筒カラム (内径 $64 \mathrm{~mm}$, 高さ $50 \mathrm{~cm}$ ) に高さ $45 \mathrm{~cm}$ となるように模擬廃棄物を充填した。模擬廃棄物にはミ キサーで粉砕したドッグフード（日本ペットフード(株), ビタワン) と木くず（三洋電機(株)，SNM-HK13）を乾 燥重量比で $1: 2$ となるように混合し, 初期含水率を 65 \%に調整したものを用いた。これをインキュベータ内 に入れ, シリカゲルを通した乾燥空気を所定流量で下部 から送った。通気管はインキュベータ内で引き回して通 気温度がインキュベータ設定温度と同じになるようにす るとともに, カラム流入直前でその温度と湿度を温湿度 計 (秼) KN ラボラトリーズ，ハイグロクロン）で計測し

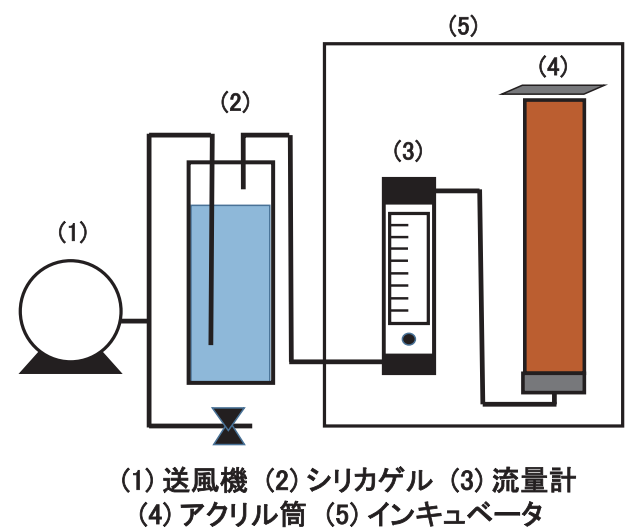

図 1 乾燥実験に用いた装置の概要

表 1 乾燥実験の材料および運転管理条件

\begin{tabular}{cccccc}
\hline \multirow{2}{*}{ 実験名 } & \multirow{2}{*}{$\begin{array}{c}\text { 材料量 } \\
\text { (gDW }\end{array}$} & \multirow{2}{*}{$\begin{array}{c}\text { 含水率 } \\
(\%)\end{array}$} & \multirow{2}{*}{$\begin{array}{c}\text { 培養温度 } \\
\left({ }^{\circ} \mathrm{C}\right)\end{array}$} & \multicolumn{2}{c}{ 通気量 } \\
\cline { 5 - 7 } & & & & $(\mathrm{L} / \mathrm{min})$ & $\left(\mathrm{L} / \mathrm{min} / \mathrm{m}^{3}\right)$ \\
\hline RUN-0.2 & 270.0 & 65 & 40 & 0.2 & 138 \\
\hline RUN-0.5 & 265.6 & 65 & 40 & 0.5 & 346 \\
\hline RUN-1.0 & 260.1 & 65 & 40 & 1.0 & 691 \\
\hline
\end{tabular}

て所定の条件が確保されていることを確認した。イン キュベータの設定温度は $40{ }^{\circ} \mathrm{C}$ とた。これは, 実験中 に観測される最高到達温度より周囲温度ならびに通気温 度を低く設定する必要がある一方で, 反応に伴う発熱に よるインキュベータ内の温度の上昇や変動を避けるには, インキュベータ内温度を室温より高めに設定する必要が あったためである。

実験条件は表 1 のとおりとし, 通気量の異なる 3 つの 実験を行った。いずれの実験でも同じ材料条件のカラム を 5 本作成して同時に同じ条件で実験を行った。 $1,3,5$, 7 および 9 日目に 1 本ずつ取り出し, カラム全体の質量 を計測してカラム内材料の湿潤重量を把握した後, 深さ 約 $5 \mathrm{~cm}$ ごとに試料を採取して含水率（湿潤重量に対す

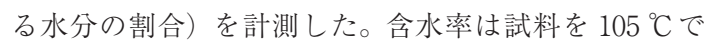
24 時間乾燥させたときの質量変化に基づいて算定した。 各層の含水率とカラム内材料の湿潤重量からカラム内材 料の乾燥重量を算定した。また，9日目まで実験を継続 するカラムにはあらかじめ廃棄物層内 $5 \mathrm{~cm}$ ごとに温度 ロガー（侏）KN ラボラトリーズ，サーモクロン）を入れ ておき, 高さごとの材料温度の時間変化を計測した。

\section{3. シミュレーションの考え方と手順}

\section{1 静置通気型反応器での反応と乾燥}

静置通気型反応器内での反応と乾燥の最大の特徴は, 
深さごとにその進み方が異なるという点である。そこで, シミュレーションプログラムを設計するにあたり, 眓 2 のように材料を深さ方向に複数の層に分け, 層ごとに反 応と乾燥のシミュレーションを行うこととした。各層の 基質消費速度 $(d S / d t)$, 微生物増殖速度 $(d X / d t)$, 水分 量変化速度 $(d W / d t)$, 温度変化速度 $(d T / d t)$, ならび に酸素濃度変化速度 $\left(d O_{2} / d t\right)$ は, その時点のその槽内 の材料条件, 環境条件ならびに直下の層から持ち込まれ る通気の量, 温度, 湿度および酸素濃度によって決まる とした。各条件に依存して反応速度および乾燥速度を求 めるための数理モデルについて以下に述べる。

\section{2 反応と乾燥の数理モデル式}

\section{2 .1 好気微生物反応に関わる数理モデル式}

まず，生物系廃棄物材料全量 $M(\mathrm{~kg})$ は, 基質 $S(\mathrm{~kg})$, 微生物 $X(\mathrm{~kg})$, 水分 $W(\mathrm{~kg})$ ならびに生物分解に関与 しない非反応物 $U(\mathrm{~kg})$ で構成されるとみなした。材料 条件と環境条件に応じた好気微生物反応速度（基質消費 速度, 微生物増殖速度, 温度変化速度, ならびに酸素濃 度変化速度）の算出については既報 ${ }^{12)}$ の数理モデルをそ のまま用いた。なお, シミュレーションに用いた数理モ デル式全体については電子付録 1 に示すこととし, 以下 では本研究で新たに付け加えることとした水分蒸発に関 わる数理モデル式と水分生成に関わる数理モデル式につ いて説明する。

3.2 .2 水分蒸発に関わる数理モデル式

\section{（1）水分量変化と水分の蒸発速度}

既報 ${ }^{12)}$ では, 反応器からの排気が常に一定の相対湿度 になっていると仮定して水分蒸発量を求め, シミュレー ションプログラムに反映させた。しかし, 静置通気型反 応器の場合, 装置下部から送られた乾燥空気は材間隙を 上に流れていくにつれて相対湿度が上昇すると考えられ る。したがって高さ方向での水分分布に配慮する必要が ある。そこで層ごとに以下の式を用いて気相中水分量変

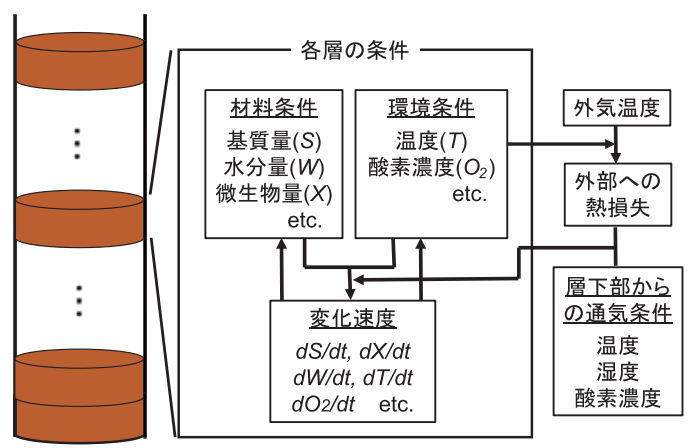

化速度を算定することとした。

$$
\frac{d W_{\text {air }}}{d t}=\frac{v_{e} D}{V_{\text {void }}}+\frac{W_{\text {air } 0} Q_{\text {in }}}{V_{\text {void }}}-\frac{W_{\text {air }} Q_{\text {out }}}{V_{\text {void }}}
$$

ここで, $W_{\text {air }}$ は空隙気相中の保有水分量 $(\mathrm{g} / \mathrm{L}), t$ は 時間 (min), $v_{e}$ は材料単位重量あたりの蒸発速度 $(\mathrm{g}-$ water $/ \mathrm{gDW} / \mathrm{min}), D$ は材料乾燥重量 (gDW), Wairo は層内流入空気の保有水分量 $(\mathrm{g} / \mathrm{L})$, Qin おょび Qout はそれぞれ層内への空気流入量および層内からの空気流 出量 $(\mathrm{L} / \mathrm{min})$, ならびに Vvoid は層内空隙体積 $(\mathrm{L})$ で ある。

また, $v_{e}$ は次式のように材料の含水率 $M C(\%)$, 気相 の相対湿度 RH (\%) および温度 $T\left({ }^{\circ} \mathrm{C}\right)$ によって決まる と考えることにした。

$$
v_{e}=v_{e s t} f_{M C}(M C) f_{R H}(R H) f_{T}(T)
$$

ここで $v_{\text {est }}(\mathrm{g}$-water $/ \mathrm{gDW} / \mathrm{min})$ は，ある相対湿度 RHst (\%) および温度 Tst $\left({ }^{\circ} \mathrm{C}\right)$ 条件下でのveの上限值, すなわち材料含水率が十分高い領域での蒸発速度である。 以後, これを標準蒸発速度と呼ぶこととする。また, $R H s t$ およ゙温度 $T s t\left({ }^{\circ} \mathrm{C}\right)$ はそれぞれ標準相対湿度お よび標準温度と呼ぶこととする。

（2）蒸発速度に対する材料含水率, 相対湿度および温度 の影響

蒸発速度に対する含水率の影響については, 著者らが

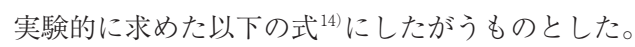

$$
\begin{aligned}
f_{M C}(M C)= & 1(M C c r \leqq M C) \\
f_{M C}(M C)= & \frac{M C-M C o}{M C c r-M C o} \\
& (M C o \leqq M C<M C c r)
\end{aligned}
$$

$$
f_{M C}(M C)=0(M C<M C o)
$$

ここで MCcr および $M C o$ はそれぞれ材料の限界含水 率および平衡含水率である。

次に, 空気相対湿度が蒸発速度に与える影響について

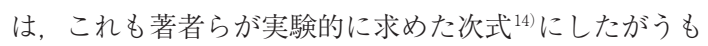
のとした。

$$
f_{R H}(R H)=\frac{100-R H}{100-R H s t}
$$

さらに, 温度が蒸発速度に与える影響については, 温 度と飽和水蒸気圧との関係を近似的に表す Antoine の 式备光用いることとした。

図 2 静置通気型反応器での反応と乾燥の考え方 


$$
f_{T}(T)=\exp \left(A-\frac{B}{T+D}\right) / \exp \left(A-\frac{B}{T s t+D}\right)
$$

ここで $A, B$ および $D$ はそれぞれ $11.961,3993.7$ およ び 233.9 として与えられる定数である ${ }^{16)}$ 。

（3）標準蒸発速度に対する通気量の影響

林は組成や含水率が同じ材料に同じ温度の乾燥空気を 送る実験を行って通気速度と蒸発速度との関係を調心， 蒸発速度と通気速度の対数との間に直線関係があること を示した ${ }^{17)}$ 。この関係を標準蒸発速度と通気量との関係 に適用すると次式のようになる。

$$
v_{\text {est }}=K \cdot \ln Q+a
$$

ここで，Kおよび $（ \mathrm{~g}$-water/gDW/min) はともに定 数である。そこで, 式(2)の $v_{\text {est }}$ には式(8)を用いて通気 量に応じた值を与えることとした。

3.2 .3 水分生成に関わる数理モデル式

材料中基質の分解にともない水分が生成されるので, これも考慮しておく必要がある。そこで以下の式を用い て水分生成速度を求めることとした。

$$
\frac{d W_{P}}{d t}=\frac{d S}{d t}\left(1-Y_{X / S}\right) \frac{M_{H_{2} O}}{M_{H_{2}}} \frac{h_{D}}{100}
$$

ここで $d W_{P} / d t$ は水分生成速度 (g-water/min), $d S /$ $d t$ は基質消費速度 $(\mathrm{g} / \mathrm{min}) ， Y_{X / S}$ は菌体収率 $(\mathrm{g}-\mathrm{cell} /$ g-substrate), $M_{H_{2} \mathrm{O}}$ および $M_{H_{2}}$ はそれぞれ水および水素 の分子量 $\left(\right.$-), ならびに $h_{D}$ は材料の水素含有率 $(\%)$ である。

\subsection{4 シミュレーションの計算手順}

上で述べた各数理モデル式を組み合わせて静置通気型 反応器での好気微生物反応をシミュレーションするプロ グラムを作成した。言語には Visual Basic 2008 を使用 した。また, 微分方程式の逐次計算には Runge-Kutta 法を用いた。

シミュレーションでの計算フローはおよそ以下のとお りである。

(1) 計算に必要な物理化学的ならびに生物学的定数, 材料条件, 運転条件および環境条件等, 計算に必 要な定数やパラメー夕を入力する。

(3) 与えられた条件の下での各量の変化速度を下層か ら上層に向かって求める。

(4) 変化速度をもとに微少時間 $\Delta t$ 経過後の各層の材 料条件と環境条件を求める。

(5) 以下, $\Delta t$ 後の材料条件と環境条件に基づいて (3) と (4)を行い, 次の $\Delta t$ 後の值を求める。これを繰 り返して材料条件と環境条件の時間変化を逐次的
に求める。

計算の結果として各層の材料乾燥重量, 水分量, なら びに温度の時間変化がテキスト形式で出力, 保存される。

なお, シミュレーションに必要なパラメー夕は電子付 録 2 に示したとおりである。また，参考までにプログラ 厶実行時の画面表示を電子付録 3 に示した。入力する定 数およびパラメータの数が多いため, 材料条件, 運転条 件, 微生物増殖速度関連の定数・ ハラメータ, 計算 - 出 力条件およびその他計算に必要な定数・パラメータに分 けて, 入力ならびに設定数值の確認が行えるように工夫 した。

\section{4. 結 果と考察}

\section{1 乾燥実験の結果}

実験結果の一例として, RUN-0.5 での層ごとの含水 率の時間変化ならびに材料温度の時間変化を図 3 ならび に図 4 に示す。いずれの実験でも図 3 にみられるように 下の層から乾燥が始まり, 含水率が顕著に低下する層が 時間経過とともに上の層に順番に移っていく現象が観測 された。また, 図 4 からは, 下の 2 層を除くと実験開始 直後から約 30 時間経過後までの間で急激な温度上昇が みられ 50 時間経過後まではインキュベータの設定温度

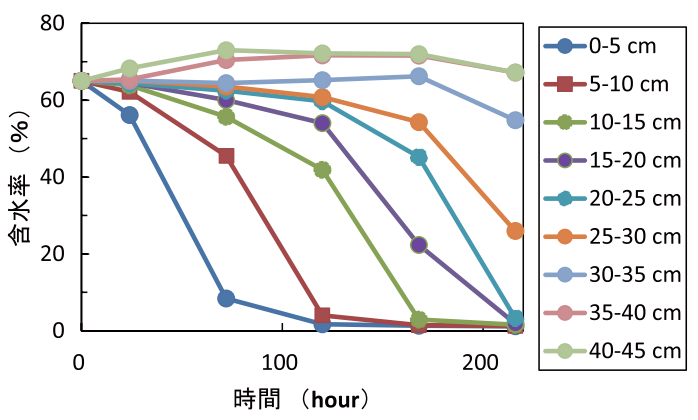

図 3 各層の含水率の時間変化 (RUN-0.5 の結果)

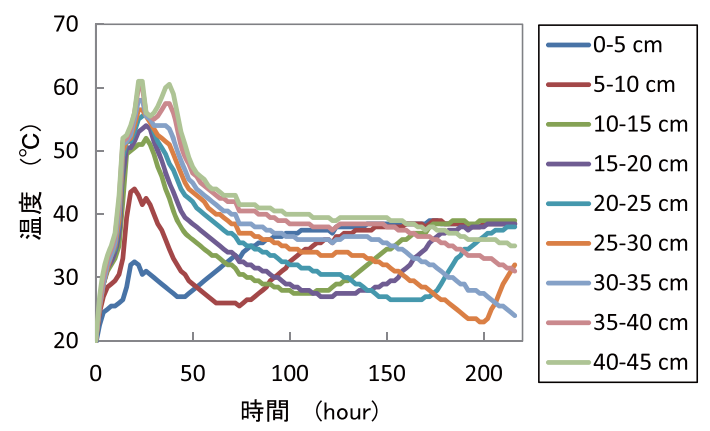

図 4 各層の温度の時間変化 (RUN-0.5 の結果) 
より高い状態であった。また，グラフは示していないが, いずれの実験でもカラム全体の乾燥質量は最初の 120 時 間までに80〜85\%まで低下し，その後は大きな変化が なかった。これらのことは, 反応初期に好気微生物反応 が活発に行われたためと推測される。

また，下部の 2 層で他の層に比べて温度が上昇しな かった原因としては, 早い時期に乾燥してしまい微生物 反応が行われにくくなったことと, 水分蒸発により気化 熱が奪われて温度が上がらなかったことが考えられる。 気化熱による温度低下については他の層でもみられ, 図 3 において, ある層の含水率低下が急激に起こっている 時間帯で, 図 4 では同じ層の温度が一時的にインキュ ベー夕設定温度より低くなるという現象が観察された。

\section{2 パラメータの設定と標準蒸発速度の較正}

シミュレーションを行うには適切なパラメータを設定 する必要がある。シミュレーションに用いた定数および パラメータを表 2 に示した。パラメータのうち実験条件 に応じて与えることができるものは実験ごとの值を与え た。また，文献から值を得ることができるものについて は文献值を与えた。各 RUN における具体的なパラメー 夕設定值を電子付録 4 に示した。また, 計算時のカラム 分割数は実験に合わせて 9 分割とした。

本研究で較正の対象としたのは標準蒸発速度 $v_{\text {est }}$ のみ である。較正は以下の手順で行った。

(1) 試行錯誤的に $v_{\text {est }}$ を変化させてシミュレーション を行って水分量と温度の時間変化を計算し, その 結果が RUN-0.2 の実験結果と最も近くなるよう

表 2 シミュレーションに用いた定数およびパラメータの概要

\begin{tabular}{|c|c|c|}
\hline 定数・パラメータ & 值 & 備 \\
\hline \multicolumn{3}{|l|}{ 材料条件関連 } \\
\hline 高さ $(\mathrm{cm})$ & 45 & 実験条件 \\
\hline カラム径（cm） & 6.4 & 実験条件 \\
\hline 初期含水率（\%） & 65 & 実験条件 \\
\hline 初期温度 ( $\left.{ }^{\circ} \mathrm{C}\right)$ & 25 & 実験条件 \\
\hline 初期湿潤重量（gWW） & a) & 実験条件 \\
\hline 初期基質含有率（\%） & 25 & 実験結果より推定 ${ }^{18)}$ \\
\hline 初期微生物含有率（\%） & 0.1 & 文献值 ${ }^{12)}$ \\
\hline 材料空隙率（\%) & 63.1 & 文献值 ${ }^{18)}$ \\
\hline \multicolumn{3}{|l|}{ 運転条件関連 } \\
\hline 初期反応器内酸素濃度（\%) & 21 & 大気条件 \\
\hline 通気量（L/min） & a) & 実験条件 \\
\hline 通気湿度（\%） & $0.1 \sim 4.4$ & 各実験での計測值平均 \\
\hline 通気温度（ ${ }^{\circ} \mathrm{C} ）$ & 40 & 実験条件 \\
\hline 反応器側面からの熱損失 $(\mathrm{J} / \mathrm{h} / \mathrm{K})$ & 1,222 & 文献值 ${ }^{18)}$ \\
\hline \multicolumn{3}{|l|}{ 微生物増殖速度 $\cdot$ 反応速度関連 } \\
\hline $\begin{array}{l}\text { 比増殖速度とこれに対する水分・温度・酸素濃度 } \\
\text { 等の影響因子に関わる定数群 }\end{array}$ & b) & 文献値 ${ }^{12)}$ \\
\hline \multicolumn{3}{|l|}{ 微生物反応の物質収支関連 } \\
\hline $\begin{array}{l}\text { 菌体収率, 単位基質費あたり酸素消費量等, 物質 } \\
\text { 収支に関わる定数群 }\end{array}$ & b) & 文献值 ${ }^{12.18)}$ \\
\hline \multicolumn{3}{|l|}{ エネルギー収支関連 } \\
\hline 単位酸素消費あたり発熱量 $\left(\mathrm{J} / \mathrm{g}-\mathrm{O}_{2}\right)$ & 16,300 & 文献值 ${ }^{19)}$ \\
\hline 水の気化熱 $(\mathrm{J} / \mathrm{g}-$ Water $)$ & 2,440 & 文献值 ${ }^{20)}$ \\
\hline 水の比熱 $(\mathrm{J} / \mathrm{g} / \mathrm{K})$ & 4.2 & 文献值 ${ }^{20)}$ \\
\hline 空気の比熱 $(\mathrm{J} / \mathrm{g} / \mathrm{K})$ & 1.01 & 文献值 ${ }^{20)}$ \\
\hline 材料の比熱 $(\mathrm{J} / \mathrm{gDW} / \mathrm{K})$ & 2.1 & 文献值 ${ }^{12)}$ \\
\hline \multicolumn{3}{|l|}{ 水分蒸発関連 } \\
\hline 標準蒸発速度（gW/gDW/min） & c) & 較正する値 \\
\hline 平衡含水率（\%） & 1 & 文献值 ${ }^{21)}$ \\
\hline 限界含水率（\%） & 30 & 文献値 ${ }^{21)}$ \\
\hline Antoine 式に関する定数群 & b) & 文献值 ${ }^{16)}$ \\
\hline
\end{tabular}

a）実験ごとに条件が変わるため, 実験条件に合わせて設定する

b) 参考文献と同じ值を与えた

c）シミュレーション結果と実験結果とを比較することで較正する 
に $v_{\text {est }}$ を調整する。この $v_{\text {est }}$ を通気量 $0.2 \mathrm{~L} / \mathrm{min}$ のときの標準蒸発速度とする。

(2) 同様に, RUN-1.0の結果を近似する $v_{\text {est }}$ を求め, これを通気量 $1.0 \mathrm{~L} / \mathrm{min}$ のときの標準蒸発速度と する。

(3)上で求めた 2 組の通気量と標準蒸発速度を式 (8) に代入して 2 つの定数 $K$ および $a$ を決定して式 を完成させる。これにより任意の流量条件での標 準蒸発速度が推計できるようになる。

図 5 および図 6 は RUN-0.2 の実験結果と, $v_{e s t}=7.0 \times$ $10^{-4} \mathrm{~g}$-water $/ \mathrm{gDW} / \mathrm{min}$ としたときのシミュレーショ

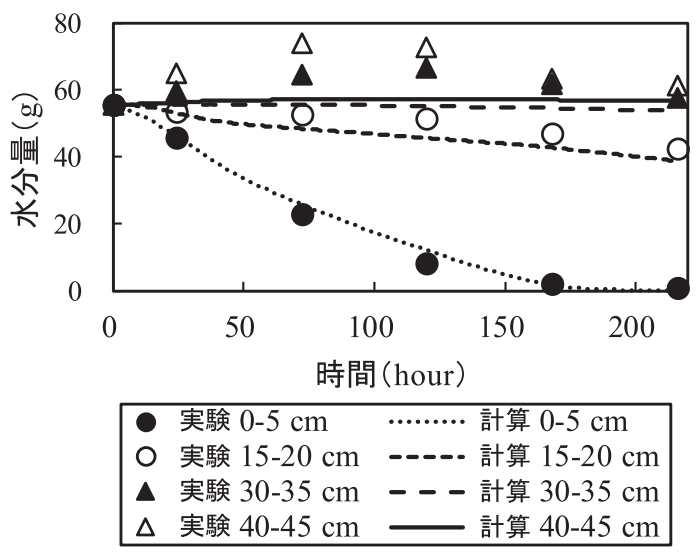

図 5 各層の水分量実験結果と較正した標準蒸発速度に 基づく水分量計算結果との比較（RUN-0.2 の場合）
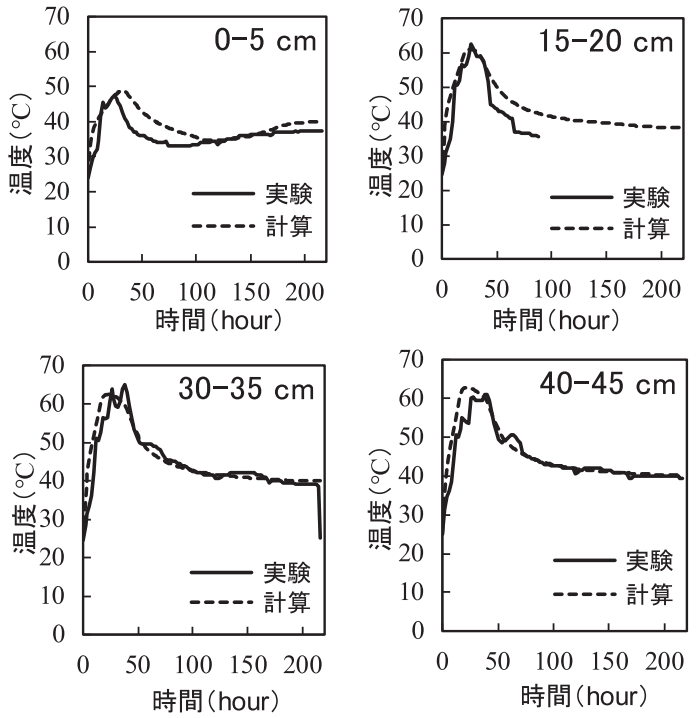

15-20 cm 層の 90 時間以降は温度ロガー不調により久測

図 6 各層の温度実験結果と較正した標準蒸発速度に基 づく温度計算結果との比較 (RUN-0.2 の場合)
ン計算結果のうち, 代表的な 4 層の水分量の時間変化お よび温度変化を示したものである。水分量に関しては, 上部の層で計算值は実験值を下回っているが，下部の層 ではお扔むね両者が一致する結果となった。また，温度 については若干の差はあるものの, おおむね一致する結 果となった。 $v_{\text {est }}$ に他の值を用いた場合, 実験結果と計 算結果の差がこれより大きくなることから, 通気量 0.2 L/min での $v_{\text {est }}$ にはこの值を用いることとした。

同様に RUN-1.0について $v_{\text {est }}$ を求めた結果, $1.3 \times$ $10^{-3} \mathrm{~g}$-water $/ \mathrm{gDW} / \mathrm{min}$ となった。これら 2 つの通気 条件の較正結果から, 本研究で用いた材料での通気量と 標準蒸発速度との関係は次式のようになった。

$$
v_{\text {est }}=3.73 \times 10^{-4} \cdot \ln Q+1.3 \times 10^{-3}
$$

\section{3 シミュレーションの妥当性}

標準蒸発速度 $v_{\text {est }}$ が較正できたので，較正済みのパラ メータを用いて通気量を $0.5 \mathrm{~L} / \mathrm{min}$ とした場合について シミュレーションを行った。このときの $v_{\text {est }}$ は式(10)に より求まる $1.04 \times 10^{-3} \mathrm{~g}$-water $/ \mathrm{gDW} / \mathrm{min}$ とした。

すべてのパラメータをあらかじめ定めて行ったシミュ レーションの結果と実験結果とを照合比較することでシ ミュレーションの妥当性を考察することとした。図 7 お よび図 8 は, RUN-0.5 の実験結果とシミュレーション の結果のうち, 代表的な 4 層での水分量の時間変化およ び温度変化を示したものである。水分量に関しては最上 層で計算值が実験值を下回る結果となったが, 少なくと も高さが下から $2 / 3$ までの層では両者がほぼ一致した。 また，温度に関しては，気化熱の影響と考えられる一時 的な温度低下は再現できたものの, 計算值のほうが温度 の下がり方が小さめになる傾向がみられ，またそのタイ

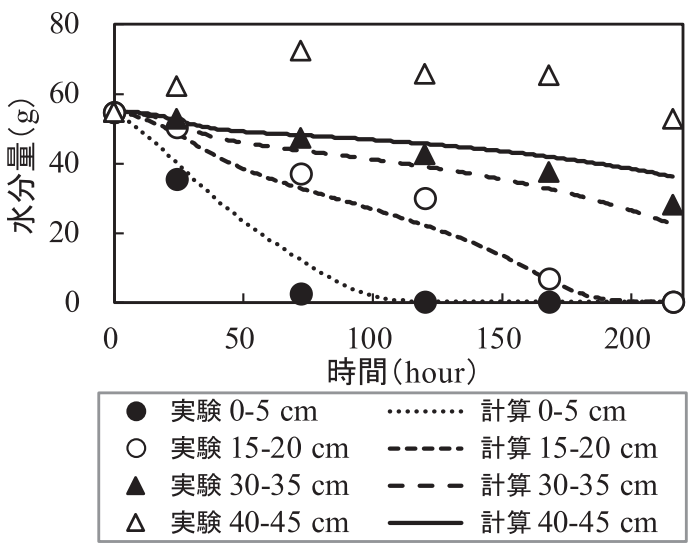

図 $7 \mathrm{RUN}-0.5$ の各層の水分量実験結果と $v_{\text {est }}=1.04 \times 10^{-3}$ $\mathrm{g}$-water/gDW/min とした場合の RUN-0.5 の水分量 計算結果との比較 

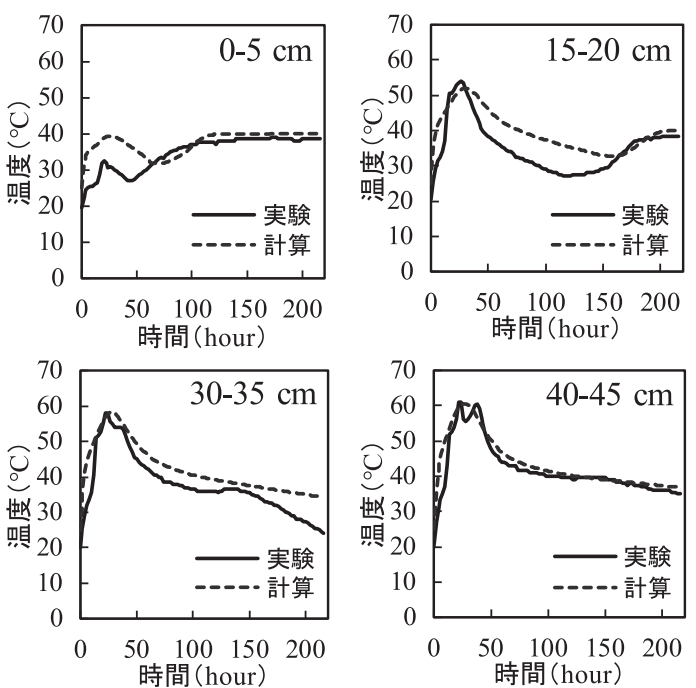

図 $8 \mathrm{RUN}-0.5$ の各層の温度実験結果と $v_{e s t}=1.04 \times 10^{-3}$ $\mathrm{g}-$ water $/ \mathrm{gDW} / \mathrm{min}$ とした場合の RUN-0.5の温度 計算結果との比較

ミングがずれることもあった。

このように水分量や温度について実験值と計算值が上 部の層で合わなくなった大本の原因としては, 基質分解 にともなう水分生成量をシミュレーションでは小さく見 積もってしまったことが考えられる。水分生成を小さめ に見積もった状況で標準蒸発速度を較正すると, 標準蒸 発速度が小さめに設定されてしまう。このような状況で も, 実験開始後の早い段階で乾燥する下の層では小さめ の水分生成に見合うように較正された蒸発速度で計算が 行われるので, 水分量の時間変化の実験值と計算值は一 致する。しかし, 上部の層では乾燥が始まるまでの間に 生成した水分はその層内に留まることになるので計算值 は実験值に比べ小さくなってしまう。

このように蒸発速度を小さめに設定した可能性がある ということは, 図 8 で一時的に温度低下が起こっている ときに計算值のほうが温度の下がり幅が小さめになって いることからも考えうることである。

\section{5. を め}

本研究では, 静置通気型反応器を用いた生物系廃棄物 の乾燥過程のシミュレーションプログラムの作成を目的 とした。パラメータの較正および妥当性の検証を行った 結果, 計算結果と実験結果とが完全に一致するまでには 至らなかったが, 実験をおおむね再現できる計算結果を 得ることができた。このことから，本シミュレーション プログラムの妥当性をお拉む確認することができた。
計算結果が実験結果と一致しなかったという問題につ いては, パラメータの值を調整することで改善できる可 能性がある。実験的に求めることのできるパラメータに ついてはこれを求めるための実験を別途行ってより正確 な值を求めることが可能である。しかし, 実験的に求め ることができないものもあるので, 本研究で行ったよう に乾燥実験を行ってその結果と合致するように較正する プロセスも必要である。今後は, パラメータを自動的に 較正する仕組みをシミュレーションプログラムに組み込 むなど妥当なパラメータ設定を行う方法について検討し たいと考えている。

\section{[謝辞］}

本研究の一部は JSPS 科研費 24561009 の助成を 受けた。ここに記して謝意を表します。

\section{参考文献}

1) 井上貴仁, 平山けい子, 平山公明, 金子栄廣: 好気性 微生物反応を利用した生物系廃棄物の乾燥による固形 燃料化, 第 42 回土木学会関東支部技術研究発表会, VII-19 (2015)

2) 和田直樹: 下水污泥有効利用の動向と国の取り組み, 土木学会誌, 第 102 巻, 第 4号, pp. 24-25（2017）

3 ）三豊市：三豊市一般廃棄物（ごみ）処理基本計画, p. 55 (2015)

4 ）三豊市：広報みとよ, 平成 28 年 8 月号 (2016)

5 ）大熊修, 林 順一, 福永泰幸, 足立義男, 増井芽, 西 田尚史, 田中努: エネルギー自立型堆肥化・炭化プロ セスの開発 (炭化設備の導入), 第 21 回廃棄物資源循 環学会研究発表会講演集, pp. 439-440（2010）

6 ）前奈緒子, 勝見 武, 乾 徹, 前一廣: エクセルギー効 率に基づくバイオマス廃棄物の変換スキーム評価法の 検討, 第 23 回廃棄物資源循環学会研究発表会講演集, pp. 333-334 (2012)

7 ）金子栄廣, 伊藤浩二郎, 平山けい子, 平山公明：好気 微生物反応を利用した生物系廃棄物の乾燥, 廃棄物資 源循環学会論文誌, 第 27 巻, pp. 1-6 (2016)

$8)$ L. Shao, Z. Ma, H. Zhang, D. Zhang and P. He: Biodrying and Size Sorting of Municipal Solid Waste with High Water Content for Improving Energy Recovery, Waste Management, Vol. 30, pp. 1165-1170(2010)

9) E. C. Rada, M. Raggazi, S. Villotti and V. Torretta : Sewage Sludge Drying by Energy Recovery from OFMSW Composting : Preliminary Feasibility Evaluation, Waste Management, Vol. 34, pp. 859-866 (2014)

10）吉川克彦, 角田芳忠 : 欧州に於ける MBT 技術動向と 事例紹介, 廃棄物資源循環学会誌, 第 27 巻, 第 5 号, pp. 325-332 (2016)

11) D. Zhang, P. He, T. Jin and L. Shao: Bio-drying of Municipal Solid Waste with High Water Content by Aeration Procedures Regulation and Inoculation, Bio- 
resource Technology, Vol. 99, pp. 8796-8802 (2008)

12）金子栄廣, 平山公明, 藤田賢二 : コンポスト化反応の

シミュレーション, 廃棄物学会論文誌, 第 12 巻, 第 3

号, pp. 122-130 (2001)

13) S. Bunrith and H. Kaneko : Simulation of Windrow Composting for Organic Solid Wastes, International Conference on Chemical, Biological and Environmental Science (ICCEBS2011), pp. 2-10 (2011)

14）金子栄廣：通気反応塔を用いた生物系廃棄物の乾燥過 程のシミュレーション, ケミカルエンジニヤリング, 第 58 巻, 第 1 号, pp. 45-48 (2013)

15）金子栄廣, 長澤拓海：通気反応塔を用いた模擬生物系 廃棄生物の乾燥, 第 27 回廃棄物資源循環学会研究発表 会講演集, pp. 259-260（2016） 16）藤田賢二：コンポスト化技術，技報堂出版，p. 44 (1993)

17）林 和希：通気によるコンポスト材料表面からの水分蒸 発に関する検討, 平成 20 年度山梨大学卒業論文 (2009)

18）伊藤浩二郎：通気反応塔を用いた生物系廃棄物の乾燥 過程のシミュレーション, 平成 26 年度山梨大学修士論 文 (2015)

19）海野 肇, 中西一弘, 白神直弘: 生物化学工学講談社サ イエンティフィク, p.59 (1992)

20）国立天文台編：理科年表平成 10 年版, 丸善出版（1998）

21）林 和希, 金子栄廣：コンポスト材料の乾燥に関する研 究, 第 20 回廃棄物資源循環学会研究発表会講演集, pp. 257-258 (2009)

\title{
Simulation of Bio-drying of Bio-waste using Static Pile Forced Aeration Reactors
}

\author{
Hidehiro Kaneko* and Kojiro Ito* \\ Interdisciplinary Graduate School, University of Yamanashi \\ $\dagger$ Correspondence should be addressed to Hidehiro Kaneko : \\ Interdisciplinary Graduate School, University of Yamanashi \\ (4-3-11 Takeda, Kofu, Yamanashi 400-8511 Japan)
}

\begin{abstract}
Generally, bio-wastes have high moisture. However, they have high caloric values if they are dried. Composting is one of the traditional recycling methods for them. It uses aerobic biological reactions. The high temperature that results from self-heat generation and the aeration for oxygen supply make the product dryer than the original. This phenomenon shows that effective drying can be achieved if this process is controlled well. However, it is not easy to find optimum operational conditions, because this process is very complicated with many environmental and operational factors. In this research, a simulation program that describes this process was developed. By comparing simulated results with the results of drying experiments, the validity of the simulation program is discussed.
\end{abstract}

Keywords : bio-waste, drying, aerobic biological reaction, static pile forced aeration reactor, simulation 